\title{
EVL wt Allele
}

National Cancer Institute

\section{Source}

National Cancer Institute. EVL wt Allele. NCI Thesaurus. Code C114826.

Human EVL wild-type allele is located in the vicinity of $14 q 32.2$ and is approximately 173

$\mathrm{kb}$ in length. This allele, which encodes Ena/VASP-like protein, plays a role in actin

polymerization. 